\title{
Improvement Of Social Studies Learning outcomes Throughthe Application Of Mindmapping Learning Model For Class V Students Of Sd Inpres 3/77 Manurungnge
}

\author{
St. Jauhar ${ }^{1}$, Bella Ambarwati ${ }^{2}$ \\ \{jauhar@unm.ac.id ${ }^{1}$, bella.ambarwati@gmail.com² $\}$ \\ ${ }^{1,2}$ PGSD FIP Universitas Negeri Makassar, Indonesia
}

\begin{abstract}
The problem found in this study is the low learning outcomes of Social Studies students in class V SD Inpres 3/77 Manurungnge Tanete Riattang District Bone Regency. The purpose of this study was to determine the increase in social studies learning outcomes through the application of Mind Mapping learning models for fifth grade students of SD Inpres 3/77 Manurungnge Tanete Riattang District Bone Regency. The approach used is a descriptive qualitative approach with Classroom Action Research (CAR) consisting of action planning, action implementation, observation, and reflection. The focus of this research is seen from the results of students' social studies learning and the application of Mind Mapping learning models. The subjects in this study were the teacher and all 16 grade $\mathrm{V}$ students, consisting of 6 men and 10 women. Data collection techniques used are observation, testing and documentation. Data analysis techniques consist of data reduction, presentation and conclusion drawing. The results showed that student learning outcomes in Cycle I with the category Fair (C) and increased to the Good category (B) in cycle II. Then it can be concluded that social studies learning outcomes can be improved through the application of Mind Mapping learning models for fifth grade students of SD Inpres 3/77 Manurungnge Tanete Riattang District Bone Regency.
\end{abstract}

Keywords: learning outcomes, mind mapping, and social studies learning

\section{Introduction}

The rapid development of science and technology in the current era of globalization, forces us to face various changes in aspects of life. As the next generation of our nation needs to develop and improve its human resources. Quality human resources is an absolute requirement that must be possessed by every nation. One vehicle for improving the quality of human resources is through education as a determining factor for the progress of a nation that is carried out in a directed and systematic manner.

Social Sciences (IPS) has become a subject that can deliver students to be able to answer basic problems about individuals, society, social institutions, social problems, social change, and the life of the nation, from time to time. Students are expected to be able to answer these questions through the substance of social studies that has been designed systematically and comprehensively. Thus, social studies are needed for students in the process towards maturity and achieving success in life in the future. 
Social studies examines a set of events, facts, concepts, and generalizations related to social issues. Social studies is a field of study in schools with the aim of developing social knowledge, attitudes, and skills in the form of concepts and learning experiences that are selected or organized in the framework of social science studies. In line with that in the 2006 Education Unit Level Curriculum (KTSP) it is stated that the objectives of Social Sciences are:[1]

1)Get to know the concepts relating to people's lives and their environment; 2) have the basic ability to think logically and critically, curiosity, inquiry, problem solving, and skills in social life; 3) have a commitment and awareness of social and human values; and 4) have the ability to communicate, cooperate and compete in a pluralistic society, at the local, national and global level.

One effort to realize these goals is through Social Studies Learning in Primary Schools. Through social studies learning in elementary schools, students are equipped with basic skills to develop knowledge, understanding, attitudes and analytical skills towards the social conditions of the community. So that in the future students will be able to face various severe challenges in the lives of global society which are always experiencing changes from time to time. Based on the explanation, it can be concluded that social studies subjects have important values in preparing reliable and competent human resources who are not only intelligent in their brains, but also smart in their attitude.

As stated: "The purpose of social studies education is to help the growth of social thinking and understanding of its concepts, and to help the growth of good citizens"[2]. Other objectives of social studies learning in elementary schools according to [1] include:

1)Obtain images about a regional environment or one's own environment; 2) get information about an area / region of Indonesia; 3) obtain knowledge about the population of Indonesia; 4) foster national awareness and insight; 5) knowing the necessities of life; 6) able to feel a progress especially the latest technology; 7) able to communicate, cooperate and compete at the local, national and international levels; 8) able to interact as cultured social beings; 9) have sensitivity to sociocultural phenomena, and 10) have high integrity towards the state and nation

Based on this opinion, the efforts made to achieve the goals of IPS are developed continuously such as improving the curriculum, because the curriculum is a very important element in achieving educational goals both national and basic education goals. In addition, efforts are made to improve social studies learning outcomes, namely improving the ability of teachers to choose learning methods and classroom management, providing textbooks, providing learning media in elementary schools. But the reality is not in line with expectations, this is based on the results of pre-research conducted. Through observation and documentation on 24, 28 and 29 January 2018 at SD Inpres 3/77 Manurungnge Tanete Riattang District Bone Regency, it was found that the midterm repeat scores for the academic year 2017/2018 grade V students in social studies subjects were still lower than the KKM score of 75 With a total of 16 students, 5 students achieved mastery or $31.25 \%$, while 11 students did not achieve mastery or $68.75 \%$ of KKM. 
Based on the results of class observations, researchers found weaknesses in the learning process caused by two factors, namely the aspects of the teacher and aspects of students. In the teacher aspect are: 1) the teacher is not guiding students, 2) the teacher is not activating students, 3) the teacher is dominant in learning. While on the aspects of students: 1) students pay less attention to learning, 2) students' interest and motivation in learning activities is low, 3) students do not understand the material well.

If the problem is left unchecked, it will adversely affect the quality and student learning outcomes of social studies learning in elementary schools. So that researchers look for solutions to the causes of the problems found to determine how to solve or overcome them using Mind Mapping models in an effort to improve student learning outcomes in class V SD Inpres 3/77 Manurunge Tanete Riattang District Bone Regency.

"Mind Mapping is a creative way for each student to produce ideas, record what is learned, or plan new assignments" [3]. Mind Mapping models are very effective in increasing the potential and overall level of understanding of students because the Mind Mapping model is one of the efforts that can be used to provide understanding of student learning processes.

Mind Mapping created by students can evoke the main ideas and remember easily. Mind Mapping is a note-taking technique to help students use their full brain potential. In addition, the Mind Mapping model is very suitable for use in social studies learning because the use of the Mind Mapping model can help students to group and associate complex social studies material, so students can understand the whole material as a whole. Based on the background of the problem, the researchers improved scientifically through Classroom Action Research (CAR) with the title Improving Social Learning Outcomes Through the Application of Mind Mapping Learning Model for Class V Students of SD Inpres 3/77 Manurugnge, Tanete Riattang District, Bone Regency.

\section{Methods}

The approach in this study uses a qualitative approach that is described descriptively. that qualitative research has characteristics, namely: [4]

1)Research is directly involved in the social setting of research; 2) it is descriptive; 3) emphasizing the meaning of the process rather than the research results; 4) using an inductive analysis approach; and 5) the researcher is the main instrument (human instrument).

This approach was chosen to describe a process of educational activities based on what happened in the field as further study material to find weaknesses and weaknesses of learning so that improvement efforts can be determined.

The type of research used is Classroom Action Research (CAR). "CAR is a form of research that is reflective by taking certain actions in order to improve and / or improve teaching practices in the classroom in a professional manner" [5]. There are four important stages in class action research namely: "1) Planning, 2) Implementation, 3) Observation, and 4) Reflection" [6].

Classroom action research (CAR) is action research conducted with the aim of improving the quality of learning practices in the classroom. In addition, CAR can also improve the quality of educational outcomes through improving classroom learning practices by developing various types of skills and increasing student motivation.

The focus of class action research are: 
1. Student learning outcomes IPS after the learning process is carried out which is described in the values of student learning outcomes obtained in social studies subjects at the end of the meeting.

2. The application of the Mind Mapping Model applied in social studies learning. Through this learning model students can give and receive information from each other in the form of subject matter in the form of small notes.

This research was conducted in class V SD Inpres 3/77 Manurungnge J1. Andalas No. 35 Watampone Tanete Riattang District Bone Regency, in the even semester of the academic year 2017/2018. The classroom situation is quite good for teaching and learning activities because it is supported by adequate facilities, maintained class cleanliness so that students can learn comfortably. The location of this study was determined based on considerations: 1) Still found students who have low learning outcomes in social studies learning; 2) in this school no class action research has been carried out that applies the Mind Mapping model; 3) there is support from the principal and teachers for the implementation of this research, and 4) this place is easily accessible by researchers.

The subjects in this study were teachers and students in class V SD Inpres 3/77 Manurungnge Tanete Riattang District Bone Regency. The number of students is 16 students, consisting of 6 men and 10 women. This research uses action plans through classroom action research, There are four important stages in classroom action research "1) Planning, 2) Implementation, 3) Observation, and 4) Reflection" [7].

\section{Action Planning}

The initial activity in this research is to design in detail about what and how actions will be taken to improve student learning outcomes in IPS subjects which include:

a. Know the basic competencies and indicators to be achieved.

b. Develop learning implementation plans (RPP)

c. Make an evaluation sheet to find out learning achievements.

d. Make teaching aids or media

e. Make observation sheets of teacher and student observations

2. Action Implementation

This activity is in the form of presenting planned learning material according to the Mind Mapping learning model.

3. Observation Stage

Activities in the form of collecting data or information to find out a series of actions in research during the learning process.

\section{Reflection Stage}

This stage is intended to thoroughly review the actions taken based on the data that has been collected and the obstacles in the evaluation in order to improve the previous evaluation. An overview of the four stages of each cycle can be presented in the following chart: 


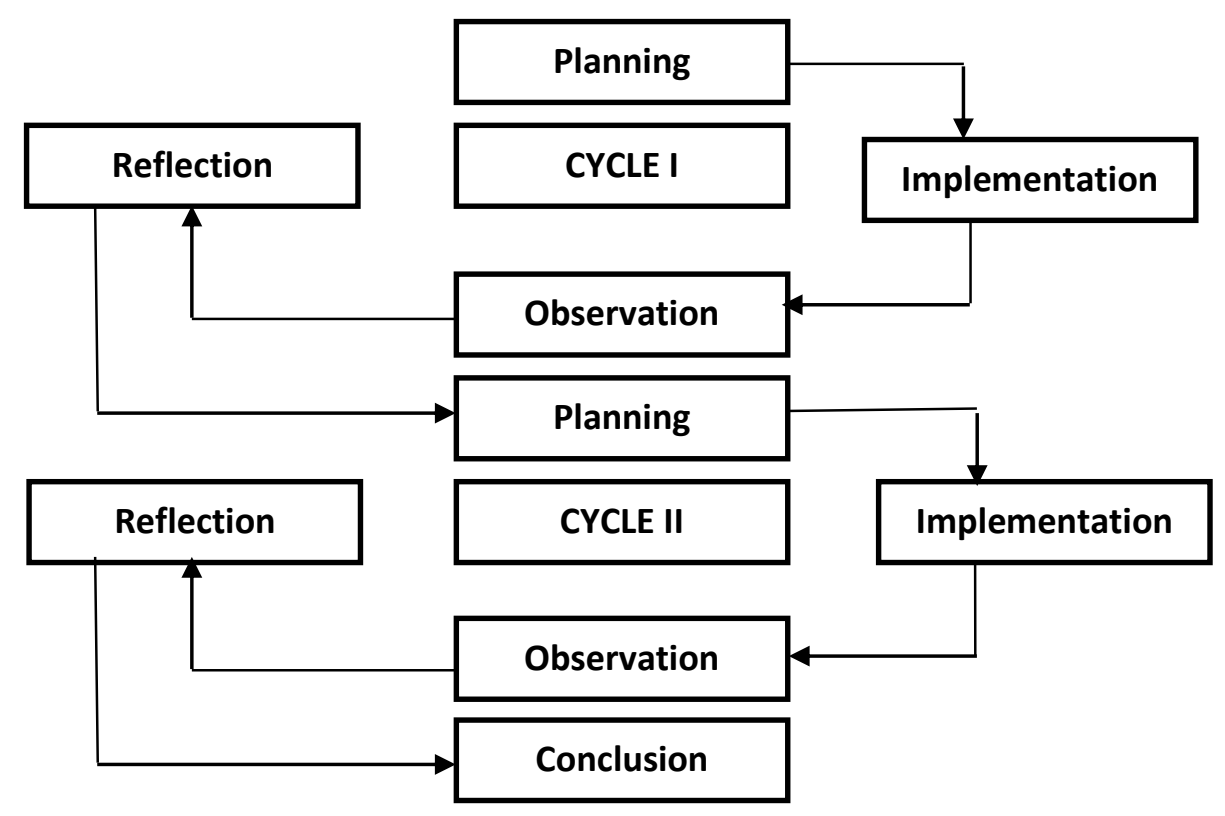

Source: Class Action Research Flow adapted from

Data collection techniques in this study were carried out by observation, tests, and documentation. The three techniques are described as follows:

a. Observation

Observation was carried out to collect data on teacher activities and student activities carried out by the observer during the learning process, using the observation sheet prepared by giving a check mark in the column provided, based on the activities carried out or not carried out by students and teachers.

b. Test

The test aims to collect data about students' social studies learning outcomes after following the teaching and learning process using the Mind Mapping learning model

c. Documentation

Documentation is an activity carried out by researchers to obtain data, in the form of midterm test scores for grade $\mathrm{V}$ students

The data collection procedures used are observation, testing and documentation.

a. Observation

This activity is carried out by an observer who has been given an explanation of the Mind Mapping learning model. The activity begins by preparing an observation sheet of teacher and student activities which will be used during the learning process by putting a check mark in the column provided.

b. Test

The test used is a written test in the form of essays which is distributed to each student which is carried out at the end of each action in accordance with the specified time of 20 minutes. 


\section{c. Documentation.}

Documentation is used to obtain preliminary data on student learning outcomes, then researchers visit and retrieve data in the form of preliminary midterm test scores. In addition, documentation is also used as an illustration in the implementation of actions.

Data analysis in this research was carried out during and after data collection. Data analysis was performed after one learning cycle was carried out as a whole. This data analysis was performed using qualitative data analysis techniques developed which consisted of three stages namely: "a. Data Reduction, b. Presentation of data (Data Display), c. Draw conclusions and verification (Conclusion Drawing) [8]. "In order to better understand these stages, the three stages are described as follows:

a. Reducing data is choosing the main points, focusing on important things, and simplifying all data that has been obtained through various sources, namely tests, observations and field notes from the initial data obtained until the preparation of the report.

b. Data display or data presentation is data presentation by narratively compiling a collection of information that has been obtained from the results of the reduction, so that it can provide the possibility of drawing conclusions and withdrawing actions. The information in question is a description of the process of learning activities, improvement of student understanding, difficulties faced by students and the results obtained as a result of giving actions. By presenting the data, it will be easier to understand what is happening, to plan further work.

c. Conclusion and verification of data, namely providing conclusions on the results of interpretation and evaluation. Conclusions are final disclosures of the results of actions based on data that has been presented

Indicators of success in Classroom Action Research (CAR) include the process and outcome indicators in research with the Mid Mapping learning model. In terms of the process seen from the activities of teachers and students in learning that uses the Mind Mapping learning model at $75 \%$ Good qualification (B). While in terms of results refer to the KKM that has been determined by the school.

The criteria used to determine the qualification level of students' social studies learning outcomes and the success of the teacher's teaching process are by referring to the following standard criteria:

Table 2.1. Qualification Level of Learning Outcomes

\begin{tabular}{ll}
\hline $\begin{array}{l}\text { Percentage } \\
\text { Completeness Level }\end{array}$ & $\begin{array}{l}\text { Learning } \\
(75-100) \%\end{array}$ \\
\hline$(59-74) \%$ & Good $(\mathrm{B})$ \\
\hline$\leq 58 \%$ & Sufficient $(\mathrm{C})$ \\
\hline Source: Educational Program Evaluation [9]
\end{tabular}

\section{Discussion}

The results of the study consisted of the findings of the success (effectiveness) of researchers in using Mind Mapping models in social studies learning in class V SD Inpres 3/77 Manurungnge Tanete Riattang District Bone Regency.

\section{a. Cycle 1}

Before carrying out research, researchers held a visit to the school that will be used as a research site. The purpose of the visit was to coordinate with the principal regarding the 
conduct of research at the school. The visit was conducted on Wednesday, January 24, 2018 which intended to meet the school principal, and fifth grade teacher of SD Inpres 3/77 Manurungnge, Tanete Riattang District, Bone Regency to discuss the research plan so that the low social studies grades of students, 5 students achieve mastery or $31.25 \%$, while 11 students who did not achieve completeness or $68.75 \%$ of the KKM determined could increase. At the meeting the school principal gave permission for conducting the research and invited to consult directly with the fifth grade teacher in setting the research plan.

Next, the researcher arranged a learning plan for this research which was planned in 2 cycles. After that the researcher consulted the fifth grade teacher in order to improve the learning plan that had been made. Researchers study the plan before taking action each cycle. Furthermore, the researcher together with the teacher compiles an observation sheet in accordance with the Mind Mapping model steps as a basis for making observations during the study. Data collection activities in this study were carried out from April 13 to April 23, 2018. The activities carried out in the first cycle include actions, planning, implementation, observation and reflection.

\section{a. $\quad$ Meeting 1}

Observation results of teacher activities obtained by observers during the learning activities of the first cycle of meeting 1 by applying the Mind Mapping learning model, namely the teacher explained the material on efforts to prepare for Indonesian independence carried out with the category Fair $(C)$ because the teacher only explained the importance of the effort and hard work of some figures in preparing independence in the form of an explanation of the formation of BPUPKI and PPKI. Then, the teacher forms a group of 4 people each implemented under the category Enough $(C)$ because the teacher forms a group (4 people) that are organized but the students conquer. After that, the teacher asks someone from the group to deliver the material that has just been received and the other group members listen and make small notes that are carried out in the Fair category (C) because the teacher only advises students to discuss without recording the results of discussions conducted by students.

The teacher asks students to take turns / randomly convey the results of their group discussions until the entire group has submitted the results of the discussion categorized as Less $(\mathrm{K})$ because the teacher only helps one group deliver the results of the discussion. Furthermore, the teacher repeats / explains the material that if not yet understood by students is categorized as Less $(\mathrm{K})$ because the teacher only repeats the subject matter. Finally, the teacher and the students conclude business material in preparing for Indonesian independence is categorized as Less $(\mathrm{K})$ because the teacher only asks 1 student to provide a conclusion regarding the material for the preparation of independence. Based on observations of the teacher activities of the first cycle of meeting 1, obtained data that the percentage of the implementation of teaching activities of teachers by applying the Mind Mapping learning model is $50 \%$.

Furthermore, the results of observations of student activities obtained by observers during the learning activities of the first cycle of meeting 1 through the application of the Mind Mapping learning model that students pay attention to the teacher's explanation of the business material in preparing for Indonesian independence are categorized to be implemented sufficiently (C) because of the 3 indicators, there are 2 indicators seen that students pay attention to the teacher's explanation in an orderly manner and students pay attention to the instructional media shown by the teacher. Then, students sit in groups categorized as Enough (C) because of the 3 indicators, there are 2 visible indicators namely students looking for group members in an orderly manner and students pay attention to the teacher's explanation of 
the given assignment. After that, one of the students from the group told the material they just received and the other group members listened and made small notes categorized as Less (K) because only a small portion of the group members were active.

Students take turns / randomly deliver the results of their group discussions until the entire group has submitted the results of the discussion as Fair (C) because some groups convey the results of the discussion. Furthermore, students look back at the material that if not yet understood is implemented with the category of Less $(\mathrm{K})$ because only a small proportion of students answer the teacher's questions correctly. Finally, the teacher and the students conclude business material in preparing for Indonesian independence which was carried out in the category of Less $(\mathrm{K})$ because of the 3 indicators, only 1 indicator was seen, namely students giving conclusions in front of their classmates. Based on the results of observations of the activities of students in cycle I meeting 1, the data obtained that the percentage of the implementation of student learning activities through the application of the Mind Mapping learning model is $50 \%$.

\section{b. $\quad$ Meeting 2}

Observation results of teacher activities obtained by observers during the learning activities of cycle I meeting 2 by applying the Mind Mapping learning model that is the teacher explains the material about the role of the characters in the effort to prepare for Indonesian independence carried out with the Good category (B) because the teacher explains the role of the characters in the business preparing for Indonesian independence. Then, the teacher forms a group of 4 people each implemented under the category Enough (C) because the teacher forms a group (4 people) that are organized but the students conquer. After that, the teacher asks someone from the group to deliver the material that has just been received and the other group members listen and make small notes that are carried out in the Fair category (C) because the teacher only advises students to discuss without recording the results of discussions conducted by students.

The teacher asks students to take turns / randomly convey the results of their group discussions until the whole group has delivered the results of the discussion categorized Good (B) because the teacher helps each group deliver the results of the discussion. Furthermore, the teacher repeats / explains the material that if not yet understood by students is categorized as Less $(\mathrm{K})$ because the teacher only repeats the subject matter. Finally, the teacher and students conclude the subject matter of the roles of figures in the effort to prepare for Indonesian independence categorized as Fair $(\mathrm{C})$ because the teacher asks 2 students to give a conclusion about the material for the preparation of independence. Based on observations of the activities of the teacher in the first cycle of meeting 2, the data obtained that the percentage of the implementation of teaching activities of teachers by applying the Mind Mapping learning model is $72.22 \%$.

Furthermore, the results of observations of student activities obtained by observers during the learning activities of cycle I meeting 2 through the application of the Mind Mapping learning model in which students pay attention to the teacher's explanation of the role of the characters in the effort to prepare for Indonesian independence are categorized to be implemented with Enough $(\mathrm{C})$ because of the 3 indicators, There are 2 indicators that are seen, namely students pay attention to the teacher's explanation in an orderly manner and students pay attention to the instructional media shown by the teacher. Then, students sit in groups categorized Enough (C) because of the 3 indicators, there are 2 indicators that are visible, namely students looking for group members in an orderly manner and students pay attention to the teacher's explanation of the assignments given. After that, one of the students 
from the group told the material they just received and the other group members listened and made small notes categorized as Fair (C) because only a large part of the group members were active.

Students take turns / randomly deliver the results of their group discussions until the entire group has submitted the results of the discussion are categorized Good (B) because each group presents the results of the discussion. Furthermore, students look back at the material that if not yet understood is implemented with the category of Less (K) because only a small proportion of students answer the teacher's questions correctly. Finally, the teacher and students conclude the material role of the characters in an effort to prepare for Indonesian independence which was carried out in the category of Less $(\mathrm{K})$ because of the 3 indicators, only 1 indicator was seen, the student giving a conclusion in front of his classmates. Based on observations of the activities of students in cycle I meeting 2, the data obtained that the percentage of the implementation of student learning activities through the application of the Mind Mapping learning model is $55.55 \%$.

\section{c. Analysis of Cycle Actions 1}

Learning in the first cycle focused on material preparation for independence at the meeting 1. Learning is carried out by applying the Mind Mapping learning model. All data recorded in cycle I was obtained through observing the implementation of action I and action II and evaluation. Based on the results of the first cycle test data obtained that student learning outcomes through the application of the learning model Mind Mapping categorized sufficiently. This is evident from the results of the first cycle test, there are 10 students who have completed grades with a percentage of completeness $62.5 \%$ and 6 students who have completed grades with a percentage of $37.5 \%$.

The lack of achievement of the indicators in the first cycle was caused by several factors arising from the teacher and students themselves. The results of the analysis and reflection of the entire set of activities that occurred in the first cycle of action indicate that the activities have not been maximally achieved, both from the activities of the teacher and students.

1) The teacher only gives questions to a few students, so that other students don't think and are not trained enough to speak up to express their ideas or opinions

2) Student activities are still a bit rigid with less response. This is because students are not accustomed to following the learning model implemented by the teacher in the classroom. Thus there are still many students who look less active in the learning process

3) Teachers lack time management. So that only a few students are given questions by the teacher.

According to the data analysis and reflection above, it was concluded that the learning process in the first cycle by applying the Mind Mapping learning model was not optimal. This is marked on the results of observations of the implementation of learning aspects of teachers and students in the first cycle carried out with the Fair category. In addition, student learning outcomes in the first cycle have not yet reached the established indicators of success which only reached $62.5 \%$ with an average of 74.5 . So it was concluded that the action of the first cycle with the Mind Mapping learning model had not been successful. Therefore, researchers make improvements by planning a cycle II. By paying attention to the findings in the first cycle, namely the stages of teacher and student activities that need to be improved include the following:

1. The teacher should give questions to all students, so that all students can think and are trained to express their ideas or opinions. 
2. The teacher should pay attention to class management so that all students can be active in the learning process

3. The teacher should pay more attention to time management so that all students can be asked questions

Learning in the second cycle by applying the Mind Mappings learning model is getting better. This is marked by the implementation of the learning process of teacher and student activities that are carried out in the Good category. This has an impact on the completeness of student learning outcomes that have reached predetermined indicators of success, which reached $75 \%$ with an average of 80.5 .

Based on preliminary data, the results of the first cycle and second cycle tests in this study showed an increase in learning outcomes in the learning process of fifth grade students of SD Inpres 3/77 Manurungnge Tanete Riattang District Bone Regency through the application of the Mind Mapping learning model. Student learning outcomes in the second cycle have reached predetermined indicators of success. This is evident from the results of the second cycle test which showed that 12 students who had completed grades with a percentage of completeness of $75 \%$ and 4 students who obtained incomplete grades of $25 \%$. So it was concluded that the application of the Mind Mapping learning model could improve the social learning outcomes of fifth grade students of SD Inpres 3/77 Manurungnge and this study was declared successful.

Based on the data presented previously, the focus of the discussion in this study is the activities of teachers and student activities in social studies learning by applying the Mind Mapping learning model for Class V students of SD Inpres 3/77 Manurungnge, Tanete Riattang District, Bone Regency. In the first cycle of the first meeting, the researcher discussed the efforts to prepare for Indonesian independence and in the first cycle of the second meeting discussed the role of prominent figures in the effort to prepare for Indonesian independence.

In the cycle I learning process, the percentage of success was not maximal. This is because of deficiencies that occur at each stage of learning activities, both those that occur in the teacher aspect as well as in the student aspect. Lacking on the teacher aspect, the teacher is less asking students to take turns / randomly conveying the results of their group discussions until the entire group has delivered the results of their discussion. The teacher repeats / explains the material if it is not understood by students. The teacher and the students conclude business material in preparing for Indonesian independence.

While the shortcomings that occur in the aspects of students are students less enthusiastic in providing material received in their group work. Students lack of attention to the subject matter that is given back. Only a few groups formulate conclusions and report the results of activities that have been carried out. Students are less active in concluding the material.

The results of the evaluation tests given at the end of the first cycle of learning showed an increase when compared with the students' scores at the time of the pre-study, from 16 students there were 5 students who achieved a percentage of completeness of $31.25 \%$ with an average grade of 69.69. While the value of the first cycle of 16 students, there are 10 students who get a percentage of completeness $62.5 \%$ with an average grade of 74.5. Although it has improved, but there are still most students who have not reached the standard of mastery learning, the researcher continues to the second cycle with the assumption that many students already understand the material taught by correcting the deficiencies that occurred in cycle I.

2. Cycle II

In the second cycle of the first meeting, the researcher discussed the events surrounding the proclamation of Indonesian independence and in the first cycle the second meeting 
discussed the figures of Indonesian independence. Based on the results of observations on the action cycle II, teacher and student activities increase, where deficiencies that occur in the first cycle can be fixed even though not as a whole.

The results of the evaluation tests given at the end of the learning process showed an increase in this second cycle. Student scores in the pre-study period, out of 16 students, there were 5 students who achieved a percentage of completeness of $31.25 \%$ with an average grade of 69.69. While the value of the first cycle of 16 students, there are 10 students who get a percentage of completeness $62.5 \%$ with an average grade of 74.5 . Then the value of the second cycle of 16 students, there are 12 students who get $75 \%$ completeness with an average grade of 80.5 . This means that the achievement of students who score $>75$ exceeds $75 \%$, so they are said to have achieved predetermined success indicators.

The above description, this research has been successful, therefore the research in the second cycle was stopped because it has reached a predetermined indicator of success. The formulation that has been built in pre-research, if the results of social studies learning can be improved through the application of the learning model of Mad Mapping for fifth grade students of SD Inpres 3/77 Manurungnge Tanete Riattang District Bone Regency has been achieved as desired. Thus, it can be concluded that there is an increase in IPS learning outcomes through the application of Mind Mapping learning models for fifth grade students of SD Inpres 3/77 Manurungnge Tanete Riattang District Bone Regency.

\section{Conclusion}

Based on the formulation of the problem, the findings and discussion, the results of this study can be concluded that the learning outcomes of social studies can be improved through the application of Mind Mapping learning model for fifth grade students of SD Inpres 3/77 Manurungnge Tanete Riattang District Bone District. Improved student learning outcomes can be seen from student learning outcomes. The results of the first cycle test are categorized Enough and have an increase in the results of the second cycle test with the Good category, so that the standard of student learning completeness is achieved.

\section{THANK-YOU NOTE}

The biggest thanks were given to the elementary school Inpres 3/77 Manurungnge Tanete Riattang District Bone Regency and to the journal organizers who provided suggestions for improving their writing and assisted with the publication of this article.

\section{References}

[1] Susanto dan Ahmad, Pengembangan Pembelajaran IPS di Sekolah Dasar. Jakarta: Prenadamedia Grup, 2014.

[2] Gunawan dan Rudy, Pendidikan IPS: Filosofi, Konsep, dan Aplikasi. Bandung: Alfabeta, 2011.

[3] Shoimin dan Aris, 68 Model Pembelajaran Inovatif dalam Kurikulum 2013. Yogyakarta: Ar-Rus Media, 2014.

[4] Iskandar, Penelitian Tindakan Kelas. Ciputat: Gaung Persada (GP) Press, 2010.

[5] Muslich dan Masnur, Melaksanakan PTK itu Mudah (Classroom Action Research). Jakarta: Bumi Aksara, 2014. 
[6] Suyadi, Penelitian Tindakan Kelas (PTK) dan Penelitian Tindakan Sekolah (PTS). Yogyakarta: Andi., 2012.

[7] Arikunto, S, Suhardjono, dan Supardi, Penelitian Tindakan Kelas. Jakarta: Bumi Aksara, 2015.

[8] Sugiyono, Metode Penelitian Pendidikan (Pendekatan Kuantitatif, Kualitatif, dan R\&D). Bandung: Alfabeta, 2015.

[9] Arikunto, S dan Cepi S.A, Evaluasi Program Pendidikan. Jakarta: Bumi Aksara, 2014.

[10] Huda, Model-Model Pengajaran dan Pembelajaran: Isu-Isu Metodis dan Paradigmatis. Yogyakarta: Pustaka Pelajar, 2014.

[11] Rusman, Pembelajaran Tematik Terpadu (Teori, Praktik Dan Penilaian). Jakarta: Rajawali Pers, 2016.

[12] Sinring, A., Abdul S., Pattaufi,\& Rudi, A, Panduan Penulisan Skripsi. Makassar: Fakultas Ilmu Pendidikan UNM, 2016.

[13] Slameto, Belajar dan Faktor-Faktor yang Mempengaruhi. Jakarta: Rineka Cipta, 2013.

[14] Supardi, Penilaian Autentik Pembelajaran Afektif, Kognitif, dan Psikomotor ( Konsep Dan Aplikasi). Jakarta: Rajawali Pers, 2015.

[15] Suprijono, Agus, Cooperative Learning (Teori \& Aplikasi PAIKEM). Yogyakarta: Pustaka Belajar, 2014.

[16] Trianto, Model Pembelajaran Terpadu: Konsep, Strategi, dan Implementasi dalam Kurikulum Tingkat Satuan Pendidikan (KTSP). Jakarta: Bumi Aksara, 2015. . Teori Belajar dan Pembelajaran. Jakarta: Prenadamedia Grup, 2015. 